Sains Malaysiana 50(8)(2021): 2241-2249

http://doi.org/10.17576/jsm-2021-5008-09

\title{
Determination of Formaldehyde from Disposal of Formaldehyde Fixed Biological Specimen Buried in Soil
}

(Penentuan Formaldehid daripada Spesimen Biologi Formaldehid Kekal yang Tertanam dalam Tanah)

\author{
MUSFIROH JANI* \& SHAFIQAH SHAHIRAH MOHAMMAD ZAKARIA
}

\begin{abstract}
Biomedical waste specifically anatomical specimens and body parts will be incinerated by a local incineration facility. However, the incineration of formaldehyde fixed specimen from hospitals poses hazardous effect to human and environment due to an exposure of highly toxic gases such as dioxins and furans. In addition, this practise is considered as non-shariah compliance by Muslim community. Thus, a safer and shariah-compliance option to dispose anatomical specimens through deep burial has been introduced. The concern has been raised on the side effect of the formaldehyde treated specimen to the environment. Formaldehyde is used widely for preservation of surgical and anatomical specimens. The formaldehyde toxicity specifically on the soil, soil water, soil animals and plants should be considered after the burial of the anotamical specimens. Thus, the aim of this study was to investigate the side effect of formaldehyde on soil after the burial of formalin fixed specimen on the environment. In this study, the amount of soil elemental distribution and formaldehyde concentration of pre-burial and post-burial of biological specimen were evaluated by using Energy Dispersive X-Ray Fluorescence (EDXRF) and Ultraviolet-Visible Spectrophotometer instrument, respectively. For EDXRF analysis at Point $C$, soil elemental distribution after burial of dead biological specimens has higher concentration compared to before the burial. The concentration of formaldehyde at Point $C$ was higher after the burial of dead biological specimen compared to before burial, which exceeds the tolerable concentration recommended by the World Health Organisation (WHO).
\end{abstract}

Keywords: Burial; formaldehyde; formalin; soil

\section{ABSTRAK}

Sisa bioperubatan terutamanya spesimen anatomi dan bahagian tubuh akan dibakar oleh kemudahan pembakaran setempat. Walau bagaimanapun, pembakaran spesimen yang dirawat dengan formaldehid daripada hospital boleh menimbulkan kesan berbahaya kepada manusia dan persekitaran disebabkan oleh pendedahan gas yang sangat toksik seperti dioksin dan furan. Tambahan pula, amalan ini dianggap sebagai tidak patuh syariah bagi komuniti Muslim. Oleh itu, pilihan yang lebih selamat dan patuh syariah untuk membuang spesimen anatomi melalui penanaman telah dicadangkan. Isu yang membimbangkan adalah kesan formaldehid pada spesimen yang dirawat kepada alam sekitar. Formaldehid digunakan secara meluas bagi pengawetan spesimen anatomi dan bedah. Ketoksikan formaldehid terutamanya ke atas tanah, air tanah, organisma dan tumbuhan pada tanah harus dipertimbangkan selepas penanaman spesimen anatomi telah dilakukan. Tujuan kajian ini adalah untuk mengkaji kesan sampingan formaldehid kepada tanah selepas penanaman spesimen anatomi. Dalam kajian ini, jumlah pengagihan unsur dalam tanah dan kepekatan formaldehid sebelum dan selepas penanaman spesimen telah ditentukan menggunakan Serakan Tenaga Pendarfluor Sinar-X (EDXRF) dan Sinar Ultra-ungu Boleh Nampak Spektrofotometer (UV-Vis). Dalam analisis EDXRF pada titik yang terdekat dengan penanaman (Titik C), didapati pengagihan unsur tanah selepas penanaman spesimen anatomi lebih tinggi berbanding sebelum penanaman. Kepekatan formaldehid pada Titik C juga lebih tinggi selepas penanaman spesimen anatomi berbanding sebelum penanaman, iaitu melebihi kepekatan yang dicadangkan oleh Organisasi Kesihatan Sedunia (WHO).

Kata kunci: Formaldehid; formalin; penanaman; tanah 


\section{INTRODUCTION}

In general, biological specimens are referred to as anatomical specimens and they were burnt by local incineration facilities (Human Tissue Authority 2015). This specimen has been preserved using formaldehyde. However, the process of incineration of biological specimens treated with formaldehyde in most hospitals gave harmful effects to humans, animals, plants and the environment. The incineration process of medical waste has been identified by the Environmental Protection Agency (EPA) as the sole largest source of dioxin air pollution ever that have occurred in the United States (Emmanuel et al. 2004). Organic compounds such as dioxins and furans will emerge if an incomplete combustion or incineration at a predetermined minimum temperature of $1200{ }^{\circ} \mathrm{C}$ occurred. In addition, chemical compounds such as heavy metals including lead, cadmium and mercury, hydrogen chloride, sulphur dioxide, fine dust particles, nitrogen oxides, products of incomplete combustion (PIC), carbon monoxide and many other pollutants will be emitted by medical waste incinerator into the atmosphere and contribute further to the air pollution (Emmanuel et al. 2004).

The methods by which biological specimens can be respectfully disposed are also very limited. Therefore, the economic way to remove specimen remains is required. In this study, environmentally friendly burial method into the soil was introduced. Incineration method was found to be non-sharia and contrary to the way of life of the Muslim community (Kandoli et al. 2019; Laurent et al. 2013; Scalenge \& Pantani 2020). Therefore, the study of the effects of formaldehyde on the environment especially on the soil was important to ensure that this method (burying of biological specimen that treated with formalin) was safe and did not pose any risk to the environment.

\section{MATERIALS AND Methods}

The soil samples were collected at Kampung Demit Cemetery, Kubang Kerian, Kelantan where it serves as biological specimen disposal site. This location is nearby HUSM Kubang Kerian, Kelantan. The soil sampling was conducted five times starting from 26 September 2018 to 3 October 2019. The first sampling was conducted before the burial process in order to get the baseline reference for the investigation of formaldehyde treated specimen while the other four sampling activities were conducted after the burial process.
Two soil samples were taken near the biological specimen disposal site containing formaldehyde at different point, while one sample was taken $2 \mathrm{~km}$ away from the biological specimen disposal area containing the formaldehyde material. Each of the soil samples was taken at $20 \mathrm{~cm}$ depth. The soil sample was collected before and after the disposal of the biological specimen. Then, this soil sample was dug by using auger with a depth of $20 \mathrm{~cm}$. After that, the soil samples were put into a zip lock bag and labelled as point $\mathrm{A}, \mathrm{B}$, and $\mathrm{C}$, where Point $\mathrm{C}$ was the closest point to the burial site. The $\mathrm{pH}$ and moisture content of the soil samples were also measured by using $\mathrm{pH}$ and moisture meter. These soil samples were taken to the laboratory to maintain or preserve its composition in the refrigerator at cool temperature $\left(4^{\circ} \mathrm{C}\right)$.

$35 \mathrm{~g}$ of soil sample was transferred into an aluminium foil. The soil sample was dried in air-oven at $80^{\circ} \mathrm{C}$ within a day of $24 \mathrm{~h}$. Small rocks, grass and any unnecessary sediments on soil samples was discarded before being crushed into small particles using mortar and pestle. Furthermore, the small particle of soil sample was passed through sieve ( $1 \mathrm{~mm})$, so that the uniform size of soil sample can be obtained. To prepare the finer particle size of soil sample, it was placed in grinder machine. Soil elemental distribution of all soil samples before and after the burial of the biological specimen treated by formaldehyde was analysed by using XRF instrument.

15 soil samples were crushed into small particles by using mortar and pestle. Soil sample was passed through sieve $(1 \mathrm{~mm})$, so that the uniform size of soil sample can be obtained. Then, this soil sample was weighed exactly 1.0 g. About $3.0 \mathrm{~mL}$ of $96 \%$ concentrated sulphuric acid solution and $300 \mu \mathrm{L}$ of $5 \%$ chromotropic acid solution were mixed together with soil samples that were weighed earlier and warmed-over boiling water bath for $1 \mathrm{~h}$ at 100 ${ }^{\circ} \mathrm{C}$ (Georghiou \& Ho 1989). Then, it was centrifuged to get the supernatant. The blank sample for sample solution was the mixture of $2 \mathrm{~mL}$ of distilled water, $3.0 \mathrm{~mL}$ of $96 \%$ concentrated sulphuric acid solution and $300 \mu \mathrm{L}$ of $5 \%$ chromotropic acid solution (Georghiou \& Ho 1989).

Stock solution of formaldehyde $(1000 \mathrm{mg} / \mathrm{L})$ was prepared by diluting $2.5 \mathrm{~mL}$ of $37 \%$ formaldehyde solution with distilled water. Standard series solution (20, 40, 60, 80, and $100 \mathrm{ppm})$ was also prepared. $412 \mathrm{~nm}$ reflectance was used as the wavelength for formaldehyde. The concentration of formaldehyde in soil sample can be obtained from peak area of the absorbance reflectance at $412 \mathrm{~nm}$ (linear line) against the standard calibration curve. 


\section{RESULTS AND DISCUSSION}

The in-situ $\mathrm{pH}$ measurement of soil samples has been conducted at three sampling points. Referring to Table 1 , the results show that the highest $\mathrm{pH}$ value is 7 , where almost every samples taken, gave the reading of $\mathrm{pH} 7$. The lowest recorded $\mathrm{pH}$ value was 5 , which located at Point A sample on the fifth sampling. Next, the $\mathrm{pH}$ values were found consistent at three sampling points for first three sampling with the $\mathrm{pH}$ value ranging from 6 to 7 which indicate neutral to slightly acidic condition.
However, there were two soil samples in the fourth and fifth sampling which showed acidic reading of $\mathrm{pH} 5$ (Point A). Point A which is loamy soil recorded moisture content ranging from 4-6, meanwhile Point $\mathrm{B}$ and $\mathrm{C}$ recorded moisture content reading 1 for all samplings. It indicated that both point $\mathrm{B}$ and $\mathrm{C}$ were dry compared to point A. Loamy soil (Point A) has the highest content of organic matter with the reading of $16.44 \%$ and the lowest is recorded at Point B (sandy soil) with $2.99 \%$ organic matter.

TABLE 1. $\mathrm{pH} /$ moisture content/organic matter of soil samples

\begin{tabular}{|c|c|c|c|}
\hline \multirow[b]{2}{*}{ Sampling } & \multicolumn{3}{|c|}{$\mathrm{pH}$ Values/Moisture content/organic matter (\%) } \\
\hline & $\begin{array}{c}\text { Point A } \\
\text { (Loamy soil) }\end{array}$ & $\begin{array}{c}\text { Point B } \\
\text { (Sandy soil) }\end{array}$ & $\begin{array}{c}\text { Point C } \\
\text { (Sandy soil) }\end{array}$ \\
\hline $\begin{array}{c}\text { First (Pre-Burial) } \\
26 / 9 / 2018 \\
2.00 \mathrm{pm}\end{array}$ & $6 / 4 / 12.81$ & $7 / 1 / 8.83$ & $7 / 1 / 8.64$ \\
\hline $\begin{array}{c}\text { Second (Post-Burial) } \\
27 / 12 / 2018 \\
11.30 \mathrm{am}\end{array}$ & 6/6/12.99 & $7 / 1 / 7.58$ & $7 / 1 / 3.72$ \\
\hline $\begin{array}{c}\text { Third (Post-Burial) } \\
3 / 4 / 2019 \\
5.30 \mathrm{pm}\end{array}$ & $6 / 4 / 12.94$ & $7 / 1 / 2.99$ & $7 / 1 / 9.21$ \\
\hline $\begin{array}{c}\text { Fourth (Post-Burial) } \\
23 / 7 / 2019 \\
9.00 \mathrm{am}\end{array}$ & $5 / 6 / 15.75$ & $7 / 1 / 5.03$ & $7 / 1 / 8.13$ \\
\hline $\begin{array}{c}\text { Fifth (Post-Burial) } \\
\text { 3/10/2019 } \\
7.42 \mathrm{am}\end{array}$ & $5 / 5 / 16.44$ & $7 / 1 / 6.74$ & $7 / 1 / 8.24$ \\
\hline
\end{tabular}

The ex-situ XRF analysis of soil samples were conducted at Point $\mathrm{C}$. The interaction of the organic substances and mineral in the soil are very complex. Elemental distribution of the soil was characterized at the burial plot pre- and post-burial. As stated earlier, Point $\mathrm{C}$ was the closest point to the buried specimens. Table 2 shows XRF analysis of the elemental distribution in soil samples Point $\mathrm{C}$ from first to fifth sampling. From the result, most elements showed significant increase in concentration $\left(\mathrm{mgkg}^{-1}\right)$ from first sampling (pre-burial) to fifth sampling (post-burial). Soil elemental distribution of post-burial of biological specimen namely $\mathrm{Al}, \mathrm{Cr}, \mathrm{Cu}$, $\mathrm{Fe}, \mathrm{K}, \mathrm{Mn}, \mathrm{Ni}, \mathrm{Pb}, \mathrm{Rb}, \mathrm{Si}, \mathrm{Sr}, \mathrm{Ti}, \mathrm{Zn}$, and $\mathrm{Zr}$ showed increment in concentration compared to pre-burial of 
biological specimen. On the other hand, elements of $\mathrm{Ba}$, $\mathrm{Ca}, \mathrm{Cl}, \mathrm{I}, \mathrm{P}$, and Te decreased in concentration over time from pre-burial to post-burial of biological specimen. Generally, the data demonstrated that the values of heavy metal detected in this study were within the safe limit recommended by US EPA Regulatory (Environmental Research Laboratory. Solid and Hazardous Waste Research Division 1983). Based on Table 2, heavy metal such as $\mathrm{Cr}, \mathrm{Cu}, \mathrm{Ni}, \mathrm{Pb}$, and $\mathrm{Zn}$ were still under acceptable limit. These metals are highly toxic even in trace quantity. However, titanium is not considered as a toxic metal even though it is heavy metal, and it does have serious negative health effects. Previous studies have shown an increase in the concentration of heavy metals in the cemetery (Barros et al. 2008). For instance, Santa Candida municipal cemetery in Brazil was found to be polluted by $\mathrm{Cr}, \mathrm{Pb}$, and $\mathrm{Ni}$. The increase in the content of this element is due to the material used for the interment of the deceased (Barros et al. 2008). In the previous study, Aphane (2018) has confirmed that the concentration of elements increased in the area of the cemetery compared to the non-cemetery area. All the elements did not show huge changes in concentration levels before (pre) and after (post) the burial of biological specimen even though the specimen has been treated by formalin.

TABLE 2. Elemental distribution by using XRF in soil sample collected from Point $C$ (the nearest sampling point with the burial location)

\begin{tabular}{|c|c|c|c|c|c|c|c|}
\hline \multirow{2}{*}{ Formula } & \multirow{2}{*}{ Atomic Number } & \multicolumn{5}{|c|}{$\begin{array}{l}\text { Element Concentration in Each Sampling } \\
\qquad\left(\mathrm{mgkg}^{-1}\right)\end{array}$} & \multirow{2}{*}{$\begin{array}{c}\text { US EPA Regulatory } \\
\text { Source: Environmental } \\
\text { Research Laboratory. } \\
\text { Solid and Hazardous } \\
\text { Waste Research Division } \\
\text { (1983) }\end{array}$} \\
\hline & & $\begin{array}{c}1^{\text {st }} \\
(\text { Pre })\end{array}$ & $\begin{array}{c}2^{\text {nd }} \\
(\text { Post })\end{array}$ & $\begin{array}{c}3^{\text {rd }} \\
(\text { Post })\end{array}$ & $\begin{array}{c}4^{\text {th }} \\
\text { (Post) }\end{array}$ & $\begin{array}{c}5^{\text {th }} \\
(\text { Post })\end{array}$ & \\
\hline $\mathrm{Al}$ & 13 & 5160 & 8000 & 7260 & 6730 & 8210 & 300000 \\
\hline $\mathrm{Ba}$ & 56 & 670 & 459 & 640 & 105 & 97.9 & 3000 \\
\hline $\mathrm{Ca}$ & 20 & 2110 & 1770 & 1670 & 835 & 761 & N.D. \\
\hline $\mathrm{Cl}$ & 17 & 183 & 135 & 157 & 16.7 & 12.4 & N.D. \\
\hline $\mathrm{Cr}$ & 24 & 34.5 & 31.4 & 47.5 & 12.3 & 10.7 & 3000 \\
\hline $\mathrm{Cu}$ & 29 & 11.7 & 15.5 & 15.7 & 0 & 0 & 4300 \\
\hline $\mathrm{Fe}$ & 26 & 6030 & 12100 & 7860 & 3100 & 3390 & 550000 \\
\hline I & 53 & 46.9 & 15.3 & 24.9 & 0 & 0 & N.D. \\
\hline K & 19 & 25400 & 26200 & 28800 & 16600 & 20000 & N.D. \\
\hline $\mathrm{Mn}$ & 25 & 278 & 457 & 316 & 145 & 134 & 3000 \\
\hline $\mathrm{Ni}$ & 28 & 13.3 & 13.3 & 17.1 & 0 & 0 & 75 \\
\hline $\mathrm{P}$ & 15 & 581 & 340 & 425 & 0 & 38.9 & N.D. \\
\hline $\mathrm{Pb}$ & 82 & 25.4 & 29.3 & 31.7 & 11.6 & 10.7 & 420 \\
\hline $\mathrm{Rb}$ & 37 & 95.8 & 119 & 119 & 40.1 & 44.5 & N.D. \\
\hline $\mathrm{Si}$ & 14 & 57400 & 48000 & 50700 & 71500 & 6530 & N.D. \\
\hline $\mathrm{Sr}$ & 38 & 70.8 & 67.5 & 76.2 & 26.2 & 28.5 & N.D. \\
\hline $\mathrm{Te}$ & 52 & 36.8 & 15.4 & 26.5 & 0 & 0 & N.D. \\
\hline $\mathrm{Ti}$ & 22 & 1410 & 1820 & 1590 & 517 & 639 & N.D. \\
\hline $\mathrm{Zn}$ & 30 & 19.3 & 39.5 & 26.9 & 10.4 & 0 & 7500 \\
\hline $\mathrm{Zr}$ & 40 & 128 & 228 & 149 & 235 & 145 & N.D. \\
\hline
\end{tabular}


In this paper, it can be said that the area after burial of dead biological specimens having a higher elemental concentration compared to the area before burial of biological specimens even in the same climate and soil texture but, those concentrations were acceptable by the US EPA Regulatory. Jonker and Olivier (2012) has analysed the distribution of trace metals in cemetery soils of the Zandfostein burial site in South Africa. The study had demonstrated that the concentration of trace elements (Li, Be, B, Ti, V, Cr, Mn, Co, Ni, Cu, Zn, As, Se, Rb, Sr, Mo, Cd, Sn, Sb, Te, Cs, Ba, La, W, Pt, Hg, Tl, Pb, Bi, U) in burial site is higher compared to offsite soil (Jonker $\&$ Olivier 2012). The research findings were similar to research done before (Spongberg \& Becks 2000). Sililo et al. (2001) has approved that the texture and surface area of the soil are interrelated. The sandy soil texture with large particle size as in Point $\mathrm{C}$ reduced its surface area per mass. This means that elements in the soil tend to be highly mobile in large quantities. Overall, all the elements obtained from XRF analysis decreased in concentration over time from the last sampling except for aluminium.
The presence of formalin was tested by using Ultraviolet-Visible (UV-Vis) Spectrophotometer. The absorbance of 15 soil sample solutions and the absorbance of standard solution are illustrated in Table 3 and Figure 1. The ex-situ formalin analysis of soil samples was conducted at three sampling points. Referring to Table 3, the results show that the highest concentration of formalin that obtained from this study was recorded on the second sampling (post burial) at Point $\mathrm{C}$ which was $175.10 \mathrm{mgL}^{-1}$ while the lowest one was recorded on the first sampling (pre burial) at Point A which was $127.22 \mathrm{mgL}^{-1}$. It exceeds the tolerable concentration recommended by the World Health Organisation (WHO). The concentration of formalin for each sampling was increasing steadily from Point A to Point C (closest point). Figure 1 shows that the concentration of formalin before burial seems lower than after burial for every sampling. Formalin concentration for each Point A, B, and C appears to rise on the second sampling and begins to drop gradually for subsequent sampling.

TABLE 3. Absorbance value of each soil sample for determination of formalin concentration

\begin{tabular}{|c|c|c|c|}
\hline \multirow[b]{2}{*}{ Sampling } & \multicolumn{3}{|c|}{ Absorbance value (nm) } \\
\hline & $\begin{array}{c}\text { Point A } \\
\text { (Loamy soil) }\end{array}$ & $\begin{array}{c}\text { Point B } \\
\text { (Sandy soil) }\end{array}$ & $\begin{array}{c}\text { Point C } \\
\text { (Sandy soil) }\end{array}$ \\
\hline \multicolumn{4}{|l|}{ First (Pre-Burial) } \\
\hline $26 / 9 / 2018$ & 2.502 & 2.742 & 2.930 \\
\hline \multicolumn{4}{|l|}{$2.00 \mathrm{pm}$} \\
\hline \multicolumn{4}{|l|}{ Second (Post-Burial) } \\
\hline $27 / 12 / 2018$ & 2.884 & 2.985 & 3.450 \\
\hline \multicolumn{4}{|l|}{$11.30 \mathrm{am}$} \\
\hline \multicolumn{4}{|l|}{ Third (Post-Burial) } \\
\hline $3 / 4 / 2019$ & 2.672 & 2.963 & 3.010 \\
\hline \multicolumn{4}{|l|}{$5.30 \mathrm{pm}$} \\
\hline \multicolumn{4}{|l|}{ Fourth (Post-Burial) } \\
\hline $23 / 7 / 2019$ & 2.612 & 2.926 & 3.004 \\
\hline \multicolumn{4}{|l|}{$9.00 \mathrm{am}$} \\
\hline \multicolumn{4}{|l|}{ Fifth (Post-Burial) } \\
\hline $3 / 10 / 2019$ & 2.582 & 2.895 & 2.938 \\
\hline $7.42 \mathrm{am}$ & & & \\
\hline
\end{tabular}




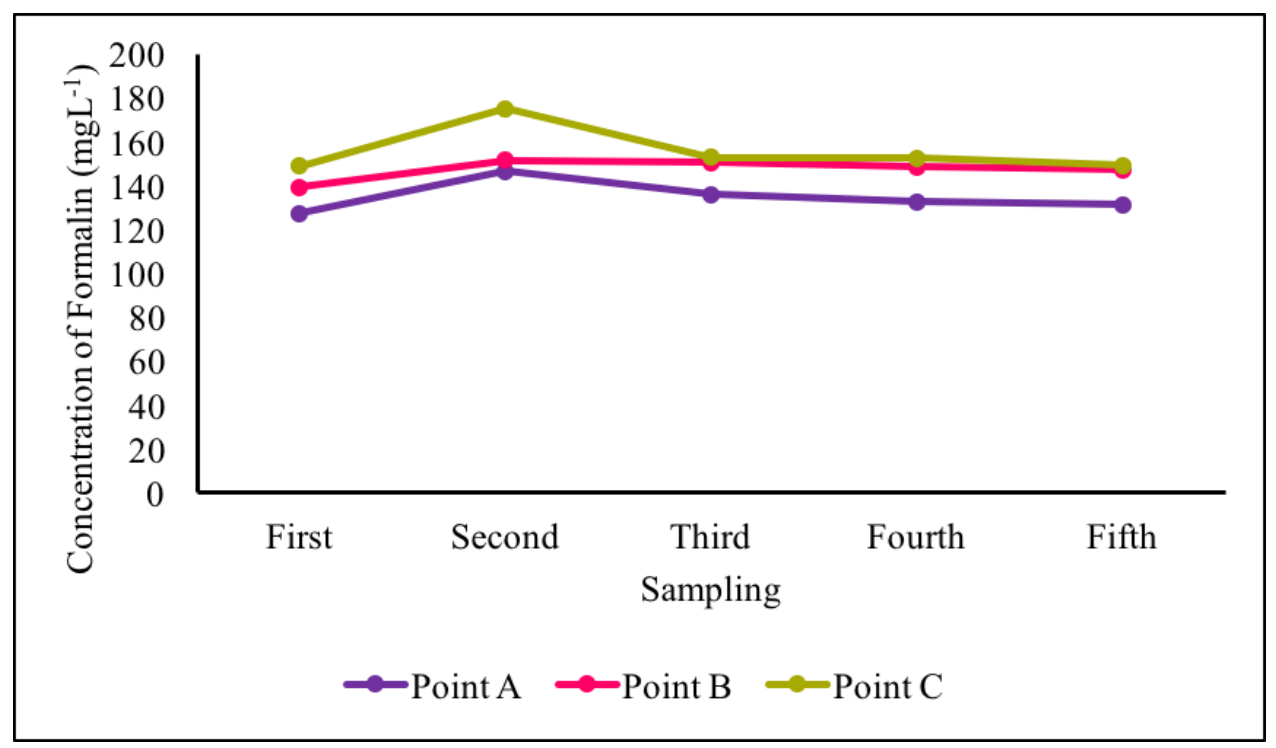

FIGURE 1. The concentration of formalin in soil samples $\left(\mathrm{mgL}^{-1}\right)$

Table 4 shows a statistical difference analysis among soil samplings and absorbance values for formaldehyde concentration. The significant difference $(p<0.05)$ was found between sample A and B, and also between A and C. A study conducted by van Allemann et al. (2018) has proven that the major sources of soil or water pollution in the cemetery area may be due to the human body, embalming fluid and coffin materials which may contain potential toxic and hazardous metals that seeping down into the ground. The research findings were similar to what have been reported on this study. Similar to what happened in Point $\mathrm{C}$, it can be said that almost all of the soil samples in Point $\mathrm{C}$ recorded higher formaldehyde concentrations than the other points since it was the closest point to the dead biological specimen's disposal site.

The concentration of formalin varies with distance and time. Figure 1 clearly shows that at Point A, the formalin concentration recorded the lowest value, while Point $\mathrm{B}$ showed the medium value and Point $\mathrm{C}$ showed the highest value. The same concept is presented by Aruomero and Afolabi (2014). The concentration of this element decreased with distance and time. Therefore, the concentration of formalin was slightly higher at Point $\mathrm{C}$ than at other points. In fact, formalin concentration for each Point A, B, and C appears to raise drastically on the second sampling and begins to drop gradually for subsequent sampling over time. In the previous study, the highest amount of formaldehyde was leached in the sandy soil at the 24 weeks was $140.2 \mathrm{mgL}^{-1}$, which was lower compared to the highest concentration of formalin that was found in this study (van Allemann et al. 2018). The highest concentration of formalin was recorded after 12 weeks burial of dead biological specimen at Point $\mathrm{C}$ was $175.10 \mathrm{mgL}^{-1}$. The high concentration of formaldehyde in the soil at sampling site was believed came from the packaging materials of biological specimens such as plastics (van Allemann et al. 2018). The Material Safety Data Sheet of Polypropylene (Plastic) states that plastics are usually made of polypropylene and contain traces of formaldehyde. On the other hand, World Health Organization (2002) also suggests that formaldehyde is a natural occurring substance in small concentrations. 
TABLE 4. Statistical difference analysis among soil sampling and absorbance value for formaldehyde concentration

\begin{tabular}{|c|c|c|}
\hline & $A$ & $B$ \\
\hline Mean & 2.6875 & 2.94225 \\
\hline Variance & 0.018561 & 0.001585 \\
\hline Observations & 4 & 4 \\
\hline Hypothesized Mean Difference & 0 & \\
\hline df & 4 & \\
\hline t Stat & -3.58964 & \\
\hline $\mathrm{P}(\mathrm{T}<=\mathrm{t})$ one-tail & 0.011485 & \\
\hline t Critical one-tail & 2.131847 & \\
\hline $\mathrm{P}(\mathrm{T}<=\mathrm{t})$ two-tail & 0.022969 & \\
\hline \multirow[t]{2}{*}{ t Critical two-tail } & 2.776445 & \\
\hline & $B$ & $C$ \\
\hline Mean & 2.94225 & 3.1005 \\
\hline Variance & 0.001585 & 0.055353 \\
\hline Observations & 4 & 4 \\
\hline Hypothesized Mean Difference & 0 & \\
\hline df & 3 & \\
\hline t Stat & -1.3264 & \\
\hline $\mathrm{P}(\mathrm{T}<=\mathrm{t})$ one-tail & 0.138322 & \\
\hline t Critical one-tail & 2.353363 & \\
\hline $\mathrm{P}(\mathrm{T}<=\mathrm{t})$ two-tail & 0.276644 & \\
\hline \multirow[t]{2}{*}{ t Critical two-tail } & 3.182446 & \\
\hline & $A$ & $C$ \\
\hline Mean & 2.6875 & 3.1005 \\
\hline Variance & 0.018561 & 0.055353 \\
\hline Observations & 4 & 4 \\
\hline Hypothesized Mean Difference & 0 & \\
\hline df & 5 & \\
\hline t Stat & -3.0382 & \\
\hline $\mathrm{P}(\mathrm{T}<=\mathrm{t})$ one-tail & 0.014405 & \\
\hline t Critical one-tail & 2.015048 & \\
\hline $\mathrm{P}(\mathrm{T}<=\mathrm{t})$ two-tail & 0.02881 & \\
\hline t Critical two-tail & 2.570582 & \\
\hline
\end{tabular}


The lowest concentration of formalin was determined at Point A which served as control soil on this study. The control soil as in Point A is however identified as the source of the formaldehyde itself, since there still has concentration of formalin too. Besides, previous study has proven that the total amount of formaldehyde leached from loamy soil much lower compared to sandy soil (van Allemann et al. 2018). That was the factor why concentration of formalin at Point A were lower compared to Point B and Point C. However, the concentration of formalin itself would remain longer in loamy soil. This may be due to the nature of the loamy soil itself which has low permeability well-drained compared to sandy soil and this implying that formalin may be retained longer in finer-grained soils (loamy) compared to coarse-grained soil (sandy).

On the other hand, according to a report released in 2002 by the World Health Organization, if formaldehyde interacts with water primarily in the soil, it can break down into methanol, amino acids, and several other types of chemicals. This is why the formaldehyde is basically not always 'trapped' in the soil or in other environments such as flora, fauna, and water. Based on the result, formalin concentration was starting to drop from second to third sampling and followed by fourth and fifth sampling. From another point of view, van Allemann et al. (2018) propose some ideas that some formalin itself will 'stick' to the soil particles and possibly slip out of the soil structure at a later stage. This will directly influence the decreasing of formaldehyde concentration slowly in soil especially on third, fourth and fifth sampling where the concentration of formalin begins to drop over time. Of the 370000 $\mathrm{mgL}^{-1}$ of formalin concentration, which was placed on dead biological specimens at Point C, only 149.24 to $175.10 \mathrm{mgL}^{-1}$ were released or leached into the soil. The rest of formaldehyde concentration can be exposed to the atmosphere in gas state and would photodegrade in sunlight only in a few hours (Hart \& Casper 2004). Hart and Casper (2004) reported that formaldehyde is highly soluble and reactive. The solubility limit for formaldehyde is $550000 \mathrm{mgL}^{-1}$. Formaldehyde concentrations can be reduced by biological systems if their concentration is not high enough to be completely toxic to the degrading organism. The highest efficiency of formaldehyde removal from wastewater was reported in both aerobic and anaerobic conditions (Garrido et al. 2000). This means that burial area of the dead biological specimen where the availability of macronutrients and micronutrients is good and very high efficiency, then the rates of formaldehyde degradation in soil may be expected to happen (Hart \& Casper 2004).

\section{CONCLUSION}

In this study, the amount of soil elemental distribution and formaldehyde concentration of pre-burial and post-burial of biological specimen were evaluated by using Energy Dispersive X-Ray Fluorescence (EDXRF) and UltravioletVisible Spectrophotometer instrument, respectively. The results showed that the soil fertility in terms of $\mathrm{pH}$ at Point $\mathrm{C}$ (closest point to burial plot) indicates neutral $\mathrm{pH}$ while its moisture content in optimum condition and the organic matter percentage was medium before burial and become low after burial within a period of three months. For X-ray Fluorescence (XRF) analysis at Point C, soil elemental distribution after burial of dead biological specimens has higher concentration compared to before the burial. According to United States of Environmental Protection Agency (US EPA) Regulatory, all the elemental distribution detected before and after burial were still below the recommended limits. Lastly, the concentration of formalin at Point $\mathrm{C}$ was higher after the burial of dead biological specimen compared to before burial. The highest and lowest concentration of formalin at Point C were 175.10 and $148.83 \mathrm{mgL}^{-1}$, respectively, which exceeds the tolerable concentration recommended by the World Health Organisation (WHO). However, the formalin concentrations were found to be decreasing with time due to its high mobility in soil and water.

\section{ACKNOWLEDGEMENTS}

The author wishes to express her gratitude to the Universiti Malaysia Kelantan, Malaysia and Universiti Sains Malaysia, Kubang Kerian Malaysia for the support received during the studies.

\section{REFERENCES}

Aphane, S.L. 2018. Assessment and modeling of contaminant transport at a burial site in Middelburg (Mpumalanga South Africa). University of Pretoria. MS. Thesis (Unpublished).

Aruomero, A.S. \& Afolabi, O. 2014. Comparative assessment of trace metals in soils associated with casket burials: Towards implementing green burials. Eurasian Journal of Soil Science 3(1): 65-76.

Barros, Y.J., Melo, V.D.F., Zanello, S., Romanó, E.N.D.L. \& Luciano, P.R. 2008. Heavy metal contents and mineralogical characterization of soils from the Santa Cândida municipal cemetery, in Curitiba (PR, Brazil). Revista Brasileira de Ciência do Solo 32(4): 1763-1773. 
Emmanuel, J., Hrdinka, C. \& Głuszyński, P., Ryder, R., McKeon, M., Berkemaier, R. \& Gauthier, A. 2004. Non-incineration Medical Waste Treatment Technologies in Europe. Prague, Czech Republic: Health Care Without Harm Europe.

Environmental Research Laboratory. Solid and Hazardous Waste Research Division. 1983. Hazardous Waste Land Treatment. Municipal Environmental Research Laboratory, Office of Research and Development, U.S. Environmental Protection Agency. p. 273.

Garrido, J., Méndez, R. \& Lema, J. 2000. Treatment of wastewaters from a formaldehyde-urea. Water Science and Technology 42(5-6): 293-300.

Georghiou, P.E. \& Ho, C.K. 1989. The chemistry of the chromotropic acid method for the analysis of formaldehyde. Canadian Journal of Chemistry 67(5): 871-876

Hart, A. \& Casper, S. 2004. Potential Groundwater Pollutants from Cemeteries. Bristol: Environment Agency. DOI:10.13140/RG.2.1.3830.2489.

Human Tissue Authority. 2015. Disposal of Anatomical Specimens, Former Anatomical Specimens and Body Parts. Human Tissue Authority. https://www.hta.gov.uk/ policies/disposal-anatomical-specimens-former-anatomicalspecimens-and-body-parts\#: : text $=$ Generally $\% 2 \mathrm{C} \% 20$ anatomical $\% 20$ specimens $\% 2 \mathrm{C} \% 20$ former $\% 20$ anatomical,part $\% 20$ of\%20any\%20disposal\%20agreements.

Jonker, C. \& Olivier, J. 2012. Mineral contamination from cemetery soils: Case study of Zandfontein Cemetery, South Africa. International Journal of Environmental Research and Public Health 9(2): 511-520.
Kandoli, S.J., Alidadib, Najafpoor, A.A., Mehrabpour, M., Hosseinzadeh, A. \& Momeni, F. 2019. Assessment of cemetery effects on groundwater quality using GIS. Desalination and Water Treatment 168: 235-242.

Laurent, M., Romain, F. \& Christophe, M. 2013. We do have space in Lausanne. We have a large cemetery: The noncontroversy of a non-existent Muslim burial ground. Social \& Cultural Geography 14(4): 428-445.

Scalenge, R. \& Pantani, O.L. 2020. Connecting existing cemeteries saving good soils (for livings). Sustainability 12(1): 93.

Sililo, O.T.N., Saayman, I.C. \& Fey, M. 2001. Groundwater Vulnerability to Pollution in Urban Catchments. Pretoria, South Africa: Water Research Commission, WRC. 1008/1/01: 38.

Spongberg, A.L. \& Becks, P.M. 2000. Inorganic soil contamination from cemetery leachate. Water, Air, and Soil Pollution 117(1): 313-327.

van Allemann, S., Olivier, J. \& Dippenaar, M.A. 2018. A laboratory study of the pollution of formaldehyde in cemeteries (South Africa). Environmental Earth Sciences 77: 20.

Faculty of Earth Science

Universiti Malaysia Kelantan

17600 Jeli, Kelantan Darul Naim

Malaysia

*Corresponding author; email: musfiroh@umk.edu.my

Received: 7 October 2020

Accepted: 28 December 2020 